Volume 4 Issue 1, March 2019: pp. 119-128. Copyright @ LamLaj. Faculty of Law, Lambung Mangkurat University, Banjarmasin, South Kalimantan, Indonesia. ISSN: 2502-3136 | e-ISSN: 2502-3128. Open Access at: http: //lamlaj.ulm.ac.id/web/

\title{
KEDUDUKAN DANA ASURANSI JIWA DALAM RELEVANSINYA DENGAN PEMBAGIAN HARTA WARISAN
}

\author{
Aji Surya Pratama ${ }^{1}$,Abdul Halim Barkatullah ${ }^{2}$, Rahmida Erliyani $^{3}$ \\ Program Magister Kenotariatan Fakultas Hukum Universitas Lambung \\ Mangkurat. Jl.Brigjend H.Hasan Basri Banjarmasin 70123 Indonesia Fax: 0511 \\ 4321658+E-mail : ajipratama33@gmail.com \\ Fakultas Hukum Universitas Lambung Mangkurat. Jl.Brigjend H.Hasan Basri \\ Banjarmasin 70123 Indonesia Fax: 05114321658 \\ +E-mail :dr.halim_barkatullah@yahoo.co.id \\ Fakultas Hukum Universitas Lambung Mangkurat.Jl.Brigjend H.Hasan Basri \\ Banjarmasin 70123 Indonesia.Fax: 05114321658 \\ +E-mail: rahmida.erliyani@gmail.com
}

Submitted : 30/11/2018 Reviewed 13/03/2019 Accepted:18/03/2019

\begin{abstract}
The aims of this research are to study and analyze the heirs whose names are not mentioned as beneficaries in life insurance policy who have been left by the deceased who can be categorized as heirs. Method of this research is normative legal research, and the type of the research vague norm, namely, there is difference or insyncronization of the Judges of the Supreme Court in making verdicts concerning disputes of fund claims of life insurance among the heirs. The results of the research shows that insurance agreement constitutes the result of combination between property law especially testametary inheritance law and contract law, thus, life insurance agreement can be called as testament because inheritance is one of the way to get right of ownership of a property, in this matter sum insured. Nomination of the heirs as beneficiaries of the fund of life insurance has a characteristic of administrative because the heirs are actually the heirs stipulated in life insurance policy. From the aspect of the inheritance property, the name stated as beneficiaries in life insurance policy can only receive maximum 1/3 (one third) of the inheritance property left by the deceased. From the aspect of their position, the heirs in life insurance policy are merely as creditors (not substituting the right and obligation of the pewaris). The legitimacy heirs are entitled to claim the right to absolute portion protected by law (legitime portie) upon the sum insured which is contrary to their legitame portion.
\end{abstract}

Keywords: Islamic Inheritance; Life Insurance; Martial Property 


\begin{abstract}
Abstrak: Tujuan dari penelitian ini adalah untuk mempelajari dan menganalisis ahli waris yang namanya tidak disebutkan sebagai penerima manfaat dalam polis asuransi jiwa yang telah ditinggalkan oleh almarhum yang dapat dikategorikan sebagai ahli waris. Metode penelitian ini adalah penelitian hukum normatif, dan jenis penelitiannya norma yang samar-samar, yaitu ada perbedaan atau insinkronisasi Hakim Mahkamah Agung dalam membuat putusan tentang perselisihan dana klaim asuransi jiwa di kalangan ahli waris. Hasil penelitian penelitian menunjukkan bahwa perjanjian asuransi merupakan hasil kombinasi antara hukum properti khususnya hukum waris testametary dan hukum kontrak, dengan demikian, perjanjian asuransi jiwa dapat disebut sebagai wasiat karena warisan adalah salah satu cara untuk mendapatkan hak kepemilikan atas sebuah properti, dalam hal ini jumlah uang pertanggungan. Nominasi ahli waris sebagai penerima dana asuransi jiwa memiliki karakteristik administrasi karena ahli waris sebenarnya adalah ahli waris yang diatur dalam kebijakan asuransi jiwa. Dari aspek properti warisan, nama yang dinyatakan sebagai penerima dalam polis asuransi jiwa hanya dapat menerima maksimal 1/3 (sepertiga) dari properti warisan yang ditinggalkan oleh almarhum. Dari aspek posisi mereka, ahli waris dalam polis asuransi jiwa hanyalah sebagai kreditor (bukan menggantikan hak dan kewajiban pewaris). Ahli waris yang sah berhak untuk mengklaim hak atas bagian absolut yang dilindungi oleh hukum (legitime portie) atas uang pertanggungan yang bertentangan dengan bagian sahnya.
\end{abstract}

Kata-Kunci: Warisan Islam; Asuransi jiwa; Properti Perkawinan

\section{PENDAHULUAN}

Asuransi berasal dari kata verzekering (Belanda) yang berarti pertanggungan. Istilah pertanggungan umummya dipakai dalam literatur hukum dan kurikulum perguruan tinggi hukum di Indonesia. Sedangkan istilah asuransi berasal dari istilah assurantie (Belanda) atau assurance (Inggris) lebih banyak dikenal dan digunakan oleh kalangan pelaku usaha (bisnis). Di Inggris, selain istilah assurance, juga terdapat istilah pendampingnya, yaitu insurance. Bila istilah assurance cenderung digunakan untuk mengidentifikasi jenis asuransi jiwa,

maka istilah insurance digunakan untuk jenis asuransi kerugian (umum). ${ }^{1}$

Pada dasarnya, asuransi atau pertanggungan adalah suatu bentuk kontrak atau persetujuan yang dinamakan polis (policy) dan menyatakan bahwa pihak satu, disebut Penanggung (insurer) menyetujui, sebagai balasan jasa, bagi suatu ganti kerugian atau dikenal sebagai premi (premium), akan membayar sejumlah uang yang telah disetujui, kepada pihak lain (yang dipertanggungkan; insured) untuk mengganti suatu kerugian, kerusakan atau luka, pada sesuatu yang berharga yang di dalamnya itu. Orang yang dipertanggungkan mempunyai insurable interest yang kadang-

1 Mulhadi. 2016. Dasar-dasar Hukum Asuransi. Medan: PT RajaGrafindo Persada, hlm. 1 
kadang disebut risiko (risk), sebagai akibat dari suatu peristiwa dan disebut hazard atau peril. Premi itu dapat dibayar dalam satu jumlah sekaligus atau angsuran; kontraknya dapat berlaku untuk satu periode tertentu atau sampai terjadinya peristiwa; risikonya dapat merupakan harta milik, harta benda kekayaan, atau keuntungan, penghasilan, atau nyawa manusia. ${ }^{2}$

Yang dimaksudkan dengan asuransi dalam kajian ini adalah pembelian manfaat Asuransi Jiwa oleh suami atau istri yang dilakukan selama perkawinan berlangsung yang berimplikasi pada harta bersama atau harta waris. Perkembangan asuransi seperti tersebut diatas khususnya dalam hal ini Dana Asuransi Jiwa yang manfaatnya dibeli oleh suami atau istri selama perkawinan berlangsung sedikit tidaknya akan berpotensi terhadap probabilitas sengketa asuransi apabila dikaitkan dengan pembagian harta warisan atau harta bersama si suami atau istri tadi meninggal dunia atau bercerai. Selama ini, sengketa asuransi khususnya asuransi jiwa didominasi oleh gugatan klaim asuransi yang di dalamnya seringkali mempersoalkan kedudukan dana asuransi apakah sebagai harta bersama, hak warisan para ahli waris atau hak individual yang nama nya tercantum di polis?

Dalam hukum perdata Islam, "belum ada kata sepakat" mengenai kedudukan dana asuransi tersebut apakah sebagai harta bersama yang dapat diwariskan ataukah menjadi hak sepenuhnya bagi penikmat yang ditunjuk dalam polis. Setidaknya ada dua putusan waris yang berbeda berkenaan dengan dana

2 A. Abdurrachman. 1991. Ensiklopedia ekonomi keuangan dan perdagangan. Jakarta: PT Pradnya Paramita, hlm. 544 asuransi tersebut, yaitu: ${ }^{3}$

a. Putusan Mahkamah Agung RI Nomor 16 K/AG/2010 tanggal 30 April 2010. Putusan ini menetapkan setengah dari nilai asuransi Rp. 50.000.000,- (lima puluh juta rupiah) adalah harta waris yang harus dibagikan. Dalam putusan ini tidak ada pertimbangan yang spesifik berkenaan dengan dana asuransi, sehingga pertimbangan hukumnya dapat dilihat pada putusan tingkat pertama dan tingkat banding. Dalam putusan Pengadilan Tinggi Agama Makasar Nomor: 59/Pdt.G/2009/ PTA.Mks tanggal 15 Juli 2009 dan putusan Pengadilan Agama Makasar Nomor 732/Pdt.G/2008/PA.Mks tanggal 2 Maret 2009 menilai dana asuransi merupakan harta bersama antara pewaris dengan istrinya karena disamping asuransi tersebut atas nama pewaris juga premi yang telah dibayarkan kepada pihak Asuransi bersumber dari harta bersama. Majelis Hakim juga mempertimbangkan mengenai polis asuransi, bahwa penunjukan istri sebagai penerima uang asuransi sifatnya admistratif karena ahli waris sesungguhnya bukan hanya istri pewaris.

b. Putusan Pengadilan Tinggi Agama Bandung Nomor: 168/Pdt.G/2012/PTA.Bdg tanggal 19 Juli 2012 yang mengoreksi putusan Pengadilan Agama Bekasi Nomor: 1526/Pdt.G/2010/PA.Bks tanggal 21 Desember 2011, sepanjang pertimbangan tentang dana asuransi, putusan tersebut telah dikuatkan oleh putusan Mahkamah Agung RI Nomor: 197K/

3 Sugiri Permana. 2016. Kajian yuridis terhadap kedudukan dana asuransi. artikel internet. http:// www.google.co.id/url?sa=t\&souce=web\&RCT= j\&url=http//journal.uinjkt.ac.id. Diakses Tanggal 15 Maret 2018. 
AG/2015 tanggal 11 Maret 2015. Putusan PTA Bandung tersebut menyertakan yurisprudensi Mahkamah Agung Nomor: 2831 K/Pdt/1996 tanggal 7 Juli 1999 dengan menegaskan bahwa dalam hukum asuransi jika terjadi evenemen (peristiwa yang tidak pasti/kematian) yang berhak menerima pembayaran uang pertanggungan adalah penikmat, biasanya berupa orang, badan, atau ahli waris yang ditunjuk dalam polis. Selain pertimbangan tersebut, asuransi tidak tunduk pada hukum perkawinan dan hukum kewarisan, oleh karenanya dana asuransi bukan harta bersama dan bukan harta warisan.

Dari dua putusan diatas menunjukan adanya perbedaan dalam menilai dana asuransi sebagai harta bersama atau sebagai hak kepemilikan tersendiri oleh penikmat/beneficiary yang tercantum dalam polis. Berdasarkan uraian-uraian tersebut di atas, maka penulis tertarik untuk mengangkat permasalahan hukum ini ke dalam sebuah karya ilmiah yang berjudul: "Kedudukan Dana Asuransi Jiwa Dalam Relevansinya Dengan Pembagian Harta Warisan".

Berdasarkan hal-hal yang diuraikan di atas maka, perlu kiranya dirumuskan dan dibatasi permasalahan-permasalahan yang dibahas dalam tulisan ini, rumusan masalah tersebut adalah sebagai berikut:

1. Bagaimana dasar pertimbangan hakim dalam membagi dana klaim tersebut pada Putusan Mahkamah Agung RI Nomor 16 k/AG/2010 dan Putusan Mahkamah Agung RI Nomor 197 K/AG/2015?

2. Apakah ahli waris yang namanya tidak tercantum sebagai penerima manfaat dalam polis asuransi jiwa yang ditinggalkan oleh pewaris bisa dikategorikan sebagai ahli waris?

\section{METODE}

Dalam hal ini penulis menggunakan jenis penelitian hukum normatif, yaitu penelitian yang mengkaji persoalan hukum dari sudut pandang ilmu hukum secara mendalam terhadap norma hukum yang dibentuk. ${ }^{4}$ Penelitian hukum ini dilakukan dengan menganalisa suatu permasalahan melalui peraturan perundang-undangan, literatur dan bahan-bahan referensi lainnya.

Penulis memilih tipe penelitian mengenai sinkronisasi hukum karena ada dua pemahaman Hakim Mahkamah Agung yang berbeda dalam hal putusan mengenai kedudukan dana asuransi. Ketidaksinkronan yang dimaksud adalah adanya perbedaan penerapan hukum dari Hakim Mahkamah Agung dalam memberikan putusan mengenai sengketa klaim dana asuransi jiwa oleh para ahli waris. Putusan pertama Mahkamah Agung Nomor $16 \mathrm{~K} /$ AG/2010 lebih melihat realitas pembayaran premi asuransi yang bersumber dari harta bersama, sehingga dana asuransi tersebut harus dijadikan sebagai harta bersama. Sebaliknya Putusan kedua Mahkamah Agung Nomor $197 \mathrm{~K} / \mathrm{AG} / 2015$ lebih bersifat legal formal, bahwa yang berhak atas dana asuransi adalah pihak yang dicantumkan dalam polis.

Penelitian ini bersifat Deskriptif Analitis yaitu penulis mengkritisi permasalahan dan memberi solusi hukum atas permasalahan yang dikaji dan dianalisa dalam penelitian hukum ini.

Dalam penelitian hukum terdapat beberapa pendekatan, dengan pendekatan tersebut penulis mendapatkan informasi dari berbagai aspek mengenai isu yang sedang dicoba untuk dicari jawabannya. Dalam penelitian ini,

4 M. Hadin Muhjad dan Nunuk Nuswardani. 2012. Penelitian Hukum Indonesia Kontemporer. Yogyakarta: Genta Publishing, hlm. 9. 
pendekatan penelitian yang digunakan adalah pendekatan:

a. Statue Approach (Pendekatan UndangUndang), yaitu pendekatan yang menelaah semua Undang-Undang dan regulasi yang berhubungan dengan isu hukum, menelaah konsistensi dan kesesuaian antara satu Undang-Undang dengan Undang-Undang lainnya atau dengan Undang-Undang Dasar, mencari "ratio legis" dan dasar ontologis perundangundangan. Pendekatan ini harus menginventarisir semua peraturan perundangundangan terkait dengan isu hukum.

b. Case Approach (Pendekatan Kasus), yaitu pendekatan dengan cara melakukan telaah terhadap kasus-kasus yang berkaitan dengan isu yang dihadapi yang telah menjadi putusan pengadilan yang telah mempunyai kekuatan hukum yang tetap.

\section{ANALISIS DAN PEMBAHASAN}

Dasar Pertimbangan Hakim Dalam Membagi Dana Klaim Pada Putusan Mahkamah Agung RI Nomor 16 K/Ag/2010 Dan Putusan Mahkamah Agung RI Nomor 197 K/AG/2015

\section{Putusan Mahkamah Agung RI Nomor} $16 \mathrm{~K} / \mathrm{AG} / 2010$

Almarhum Ir. Muhammad Armaya bin Renreng semasa hidup beragama Islam dan secara defacto atau pada kenyataannya tergugat/pemohon kasasi sampai sebelum dilakukan gugatan adalah selaku pihak yang menguasai penuh objek harta warisan almarhum Ir. Muhammad Armaya bin Renreng, oleh karena itu tepat penyelesaian sengketanya di Pengadilan Agama Makassar. Pengadilan Agama Makassar dan Pengadilan Tinggi Agama Makassar telah salah menerapkan hukum atau bertentangan dengan hukum yang men- gabulkan gugatan para Penggugat/Termohon kasasi sebagai ahli waris dari Almarhum dan berhak mewarisi 1/2 (separuh) bagian dari harta-harta yang sebagaimana tersebut dalam Putusan Pengadilan Tinggi Agama Makasar.

Secara fakta hukum, putusnya perkawinan antara pemohon kasasi/tergugat dengan Almarhum bukan karena perceraian melalui Pengadilan melainkan perceraian karena kematian dan mengenai hal tersebut telah diatur dalam ketentuan hukum baik dalam Undang-Undang Nomor 1 Tahun 1974 tentang Perkawinan dan maupun dalam ketentuan Kompilasi Hukum Islam (KHI). Secara hukum pemohon kasasi/tergugat berkedudukan hukum sebagai ahli waris utama/pokok oleh karena putusnya perkawinan karena kematian, bukan karena perceraian melalui Pengadilan. Sehingga secara hukum otomatis atau serta merta harta warisan yang ditinggalkan oleh suaminya almarhum Ir. Muhammad Armaya bin Renreng adalah merupakan harta gono-gini (harta bersama dalam perkawinan mereka) yang mana separuh atau 1/2 dari harta bersama dalam perkawinan haruslah jatuh kepada pemohon kasasi/tergugat sebagai istri sah sesuai dengan bunyi Pasal 35 ayat 1 Undang-Undang Nomor 1 Tahun 1974 tentang Perkawinan yang berbunyi "harta benda yang diperoleh selama perkawinan menjadi harta bersama. "Apalagi proses perkawinan mereka dilakukan secara pencatatan sipil pada kantor catatan sipil yang secara ketentuan perkawinannya tunduk pada ketentuan hukum perdata (BW) dan maupun Undang-undang Nomor 1 Tahun 1974 tentang Perkawinan.

Perkawinan pewaris dengan pemohon kasasi cukup lama yaitu 18 tahun, berarti cukup lama pula pemohon kasasi mengabdikan diri pada pewaris, karena itu walaupun pemohon kasasi/tergugat adalah Non Muslim 
sangatlah layak dan adil untuk memperoleh hak-hak nya selaku istri untuk mendapat bagian dari harta peninggalan berupa wasiat wajibah serta bagian harta bersama sebagaimana yurisprudensi Mahkamah Agung RI dan sesuai Asas Keadilan berimbang dalam hukum kewarisan Islam, Asas ini mengandung arti bahwa harus senantiasa terdapat keseimbangan antara hak dan kewajiban, antara yang diperoleh seseorang dengan kewajiban yang harus ditunaikannya. Laki-laki dan perempuan misalnya mendapatkan hak yang sebanding dengan kewajiban yang dipikulnya masingmasing (kelak) dalam kehidupan keluarga dan masyarakat. dalam sistem kewarisan Islam, harta peninggalan yang diterima oeh para ahli waris dari pewaris pada hakikatnya adalah pelanjutan tanggung jawab pewaris terhadap keluarganya. Oleh karena itu, perbedaan pembagian yang diterima oleh masing-masing ahli waris berimbang dengan perbedaan tanggung jawab masing-masing terhadap keluarga ${ }^{5}$. Sedangkan Yang dimaksud dengan wasiat wajibah adalah suatu wasiat yang diperuntukkan kepada ahli waris atau kerabat yang tidak memperoleh bagian harta warisan dari orang yang wafat karena adanya suatu halangan, wasiat wajibah dalam pelaksanaannya tidak dipengaruhi atau tidak bergantung kepada kemauan atau kehendak si yang meninggal dunia. ${ }^{6}$

Dalam Putusan Mahkamah Agung RI Nomor 16 K/AG/2010 tanggal 30 April 2010. Putusan ini menetapkan setengah dari nilai asuransi Rp. 50.000.000,- (lima puluh juta rupiah) adalah harta waris yang harus dibagikan. Dalam putusan ini tidak ada pertimban-

5 Sayuti Thalib. 2016. Hukum Kewarisan Islam di Indonesia. Jakarta: Sinar Grafika, hlm.17.

6 Suparman Usman. 2002. Fiqih Mawaris. Jakarta: Gaya Media Pratama, hlm. 75. gan yang spesifk berkenaan dengan dana asuransi, sehingga pertimbangan hukumnya dapat dilihat pada putusan tingkat pertama dan tingkat banding. Dalam putusan Pengadilan Agama Makassar Nomor 732/Pdt.G/2008/ PA.Mks tanggal 2 Maret 2009 dan putusan Pengadilan Tinggi Agama Makasar Nomor: 59/Pdt.G/2009/PTA.Mks tanggal 15 Juli 2009 menilai dana asuransi merupakan harta bersama antara pewaris dengan istrinya karena disamping asuransi tersebut atas nama pewaris juga premi yang telah dibayarkan kepada pihak Asuransi bersumber dari harta bersama. Majelis Hakim juga mempertimbangkan mengenai polis asuransi, bahwa penunjukan istri sebagai penerima uang asuransi sifatnya admistratif karena ahli waris sesungguhnya bukan hanya istri pewaris.

Telah diketahui bahwa asuransi termasuk bentuk mu'amalah antara sesama manusia, juga sangat penting bagi kepala keluarga yang mempunyai tanggung jawab atas kehidupan keluarganya apabila dia sudah tiada.Lalu bagaimana dengan kelangsungan kehidupan keluarganya dikemudian hari bisa tercukupi. Islam sendiri mengajarkan bahwa meninggalkan ahli waris dalam keadaan kecukupan lebih utama daripada meninggalkannya dalam keadaan kekurangan (dalam QS. An Nisa (4): 9). Asuransi jiwa dapat memberikan kebutuhan ekonomi yang diperlukan karena perusahaan asuransi jiwa akan memberikan pembayaran bagi nasabah yang masih hidup setelah habis masa kontrak dan apabila nasabah meningal sebelum habis akhir pembayaran premi, maka ahli warisnya yang berhak menerima nilai asuransi (nilai sesuai yang dicantumkan dalam polis).

Harta warisan adalah semua harta benda yang ditinggalkan oleh seorang yang meninggal (pewaris). Jadi bentuk dari harta warisan 
tidak dibedakan apakah masih berupa tulisan (seperti polis) ataukah sudah berwujud harta benda. Islam sendiri memberikan batasan bahwa warisan adalah harta dari seseorang yang meninggal dunia berupa: ${ }^{7}$

1. Harta kekayaan yang berwujud dan dapat di nilai dengan uang termasuk didalamnya piutang yang hendak ditagih. (aktiva)

2. Harta kekayaan yang merupakan utangutang yang harus dibayar pada saat meninggal dunia. (pasiva)

3. Harta kekayaan yang masih bercampur dengan harta bawaan masing-masing suami-isteri.

Jelas disini bahwa polis asuransi dapat dianggap sebagai harta warisan yang harus dibagi kepada para ahli waris sah menurut Undang-Undang karena termasuk dalam piutang (aktiva) yang akan didapat dari perusahaan asuransi.

\section{Putusan Mahkamah Agung RI Nomor $16 \mathrm{~K} / \mathrm{AG} / 2010$}

Dalam pokok perkara, harta-harta dalam perkawinan antara Almarhumah dengan suaminya adalah merupakan hasil pencaharian almarhumah sendiri, berdasarkan Kompilasi Hukum Islam di Indonesia yang berlaku pada penduduk Indonesia yang beragama Islam, maka Tergugat dan para Penggugat sebagai saudara-saudara almarhumah dalam situasi yang wajar adalah ahli waris secara bersama-sama dengan porsi yang berbedabeda. Dalam situasi normal, para Penggugat sebagai saudara-saudara almarhumah mendapat sepertiga bagian, sedangkan suami mendapat separuh bagian setelah dipotong kewajiban-kewajiban dan wasiat almarhumah sebagaimana diatur dalam Kompilasi Hukum

7 Faturrahman. 2000. Ilmu Waris. Bandung: PT.Al Ma’arif, hlm. 93.
Islam Buku II (Hukum Kewarisan) Pasal 179 yang berbunyi "Duda mendapat separuh bagian, bila pewaris tidak meninggalkan anak, dan bila pewaris meninggalkan anak, maka duda mendapat seperempat bagian." dan Pasal181 yang berbunyi "Bila seseorang meninggal tanpa meninggalkan anak dan ayah, maka saudara laki-laki dan saudara perempuan seibu masing-masing mendapat seperenam bagian. Bila mereka itu dua orang atau lebih maka mereka bersama-sama mendapat sepertiga bagian."Berdasarkan ketentuan hukum waris tersebut, Tergugat dan para Penggugat, mewarisi karena ketentuan Undang-Undang yang haknya timbul sejak detik almarhumah meninggal.

Hukum kewarisan Islam faraidh adalah salah satu bagian dari keseluruhan hukum Islam yang mengatur peralihan Harta dari orang yang telah meninggal dunia kepada orang (keluarga) yang masih hidup. Hukum kewarisan Islam mengandung berbagai asas yang memperlihatkan bentuk karakteristik dari hukum kewarisan Islam itu sendiri. Salah satunya adalah asas Individual ${ }^{8}$. Hukum Islam mengajarkan Asas kewarisan secara Individual, dalam arti harta warisan dapat dibagibagi pada masing-masing ahli waris untuk dimiliki secara perorangan. Dalam pelaksanaanya, masing-masing ahli waris menerima bagiannya tersendiri tanpa terikat dengan ahli waris yang lain. Keseluruhan harta warisan dinyatakan dalam suatu nilai tertentu dan kemudian jumlah tersebut dibagikan kepada setiap ahli waris yang berhak menerimanya.

Sepanjang pertimbangan tentang dana asuransi, Putusan Pengadilan Agama Bekasi Nomor: 1526/Pdt.G/2010/PA.Bks tanggal 21 Desember 2011 yang telah dikoreksi oleh Pengadilan Tinggi Agama Bandung dengan

$8 \quad$ Ibid., hlm. 23-28. 
putusan Nomor: 168/Pdt.G/2012/PTA.Bdg tanggal 19 Juli 2012, dan Putusan tersebut telah dikuatkan oleh putusan Mahkamah Agung RI Nomor: 197K/AG/2015 tanggal 11 Maret 2015. Putusan PTA Bandung tersebut menyertakan yurisprudensi Mahkamah Agung Nomor: $2831 \mathrm{~K} / \mathrm{Pdt} / 1996$ tanggal 7 Juli 1999 dengan menegaskan bahwa dalam hukum asuransi jika terjadi evenemen (peristiwa yang tidak pasti/kematian) yang berhak menerima pembayaran uang pertanggungan adalah penikmat, biasanya berupa orang, badan, atau ahli waris yang ditunjuk dalam polis. Selain pertimbangan tersebut, asuransi tidak tunduk pada hukum perkawinan dan hukum kewarisan, oleh karenanya dana asuransi bukan harta bersama dan bukan harta warisan.

Dalam kajian hukum perdata, dana asuransi bukan sebagai harta bersama dan bukan harta warisan, tetapi menjadi hak orang yang disebutkan dalam polis sebagai penikmat. J. Satrio menjelaskan bahwa penilaian dana asuransi bukan sebagai harta waris dilihat dari waktu perolehannya. Oleh karena dana asuransi diperoleh setelah terjadi kematian, maka dana tersebut bukan sebagai harta waris. ${ }^{9}$ Kedudukan dana asuransi tersebut telah ditegaskan dalam putusan Mahkamah Agung Nomor: 2831 K/Pdt/1996 tanggal 7 Juli 1999. Yurisprudensi tersebut mengandung dua kaidah hukum. Pertama, pembayaran uang asuransi harus diberikan kepada tertanggung yang namanya tercantum dalam polis, sehingga sesuai dengan adagium setiap pembayaran uang asuransi harus selalu melihat polis secara transparan akan menunjuk siapa yang berhak menerima uang klaim. Kedua, pembayaran uang asuransi yang menyimpang dari ketentuan Polis merupakan perbuatan mela-

9 J.Satrio. 2002. HukumWaris di Indonesia. Bandung: Alumni,hlm. 11. wan hukum. ${ }^{10}$

Harta yang dibagi waris adalah masalah status kepemilikan, bahwa harta itu adalah harta milik almarhum sejak masih hidup atau harta yang baru datang setelah kematian almarhum, dimana harta itu sebelumnya bukan milik almarhum dan statusnya bukan termasuk harta yang diwariskan. Dalam kasus posisi tersebut diatas Majelis Hakim berpendapat bahwa dalam hal uang santunan/ klaim asuransi jiwa yang berhak menerima pembayaran uang pertanggungan adalah penikmat, biasanya berupa orang, badan, atau ahli waris yang ditunjuk dalam polis. Selain pertimbangan tersebut, asuransi tidak tunduk pada hukum perkawinan dan hukum kewarisan, oleh karenanya dana asuransi bukan harta bersama dan bukan harta warisan. Menurut J.Satrio dana asuransi bukan sebagai harta waris dilihat dari waktu perolehannya. Oleh karena dana asuransi diperoleh setelah terjadi kematian, maka dana tersebut bukan sebagai harta waris. Pada praktiknya ketika masih hidup almarhum membayar uang premi kepada perusahaan asuransi yang diniatkan untuk dijadikan investasi bagi ahli waris yang telah ditunjuknya untuk menerima santunan uang dari perusahaan asuransi itu jika kelak ia meninggal dunia. Maka uang premi asuransi yang dulu dibayarkannya itu, sejatinya sudah berstatus sebagai pemberian atau hibah yang diberikan kepada ahli waris yang ditunjuknya itu.karena statusnya menjadi hibah, maka uang klaim asuransi tersebut hanya menjadi pihak yang telah ditunjuk amarhum.

Dari dua putusan di atas menunjukan adanya perbedaan dalam menilai dana asuransi sebagai harta bersama atau sebagai hak kepemilikan tersendiri oleh penikmat/beneficiary

10 Mahkamah Agung RI. 2000. Yurisprudensi Mahkamah Agung RI. Jakarta: MARI, hlm. 1. 
yang tercantum dalam polis. Putusan pertama lebih melihat realitas pembayaran premi asuransi yang bersumber dari harta bersama, sehingga dana asuransi tersebut harus dijadikan sebagai harta bersama. Sebaliknya Putusan keduabahwa yang berhak atas dana asuransi adalah pihak yang dicantumkan dalam polis. Dalam Putusan yang kedua, Kedudukan dana asuransi tersebut telah ditegaskan dalam putusan Mahkamah Agung Nomor: $2831 \mathrm{~K} /$ Pdt/1996 tanggal 7 Juli 1999. Yurisprudensi tersebut mengandung dua kaidah hukum. Pertama, pembayaran uang asuransi harus diberikan kepada tertanggung yang namanya tercantum dalam polis, sehingga sesuai dengan adagium setiap pembayaran uang asuransi harus selalu melihat polis secara transparan akan menunjuk siapa yang berhak menerima uang klaim. Kedua, pembayaran uang asuransi yang menyimpang dari ketentuan Polis merupakan perbuatan melawan hukum.

Terdapat perbedaan sumber hukum untuk menilai sengketa asuransi yang terdapat di lingkungan peradilan umum dan peradilan agama.Sengketa asuransi pada lingkungan peradilan umum diselesaikan dengan hukum perdata, sedangkan pada peradilan agama dilakukan dengan hukum perdata Islam. Menurut hukum perdata, dana asuransi menjadi hak penuh pihak yang ditunjuk dalam polis asuransi. Ketentuan tersebut berbeda dengan hukum perdata Islam yang mempunyai tiga pendapat ${ }^{11}$. Pendapat pertama, apabila dana asuransi berasal dari asuransi wajib (misalnya asuransi kecelakaan Jasa Raharja), dana (santunan) tersebut menjadi hak janda/duda. Pendapat kedua, dana asuransi menjadi harta bersama di mana sebagiannya menjadi harta

11 Muhammad Syakir Sula. 2004. Asuransi Syariah Konsep dan Sistem Operasional. Jakarta: Gema Insani Press, hlm. 31. waris (suami/istri) yang meninggal lebih dahulu. Pendapat ketiga, dana asuransi menjadi hak penuh pihak/ahli waris yang tercantum dalam polis asuransi.Pada dasarnya sengketa asuransi dapat diselesaikan pada lingkungan peradilan umum dan peradilan agama.Jenis asuransi menjadi kriteria utama untuk menentukan apakah sengketa tersebut menjadi kewenangan peradilan umum atau peradilan agama. Apabila sengketa tersebut bersumber dari asuransi syariah, penyelesaiannya menjadi kewenangan peradilan agama, sebaliknya jika sengketa tersebut berasal dari asuransi konvensional akan menjadi kewenangan peradilan umum. Peradilan agama juga berwenang menyelesaikan sengketa dana asuransi, jika dana tersebut menjadi bagian dari sengketa perdata yang menjadi kewenangan peradilan agama (harta bersama dan waris) ${ }^{12}$

Kedudukan Ahli Waris Yang Namanya Tidak Tercantum Sebagai Penerima Manfaatn Dalam Polis Asuransi Jiwa Yang Ditinggalkan

Purwosutjipto dalam bukunya mendefinisikan pengertian asuransi jiwa itu: ${ }^{13}$ "Pertanggungan jiwa adalah perjanjian timbal balik antara penutup (pengambil) asuransi dengan Penanggung, dengan mana penutup (pengambil) asuransi mengikatkan diri selama jalannya pertanggungan membayar uang premi kepada Penanggung, sedangkan Penanggung sebagai akibat langsung dan meninggalnya orang yang jiwanya dipertanggungkan atau telah lampaunya suatu jangka waktu yangdiperjanjikan, mengikatkan diri untuk membayar sejumlah uang tertentu kepada orang yang ditunjuk oleh penutup (pengam-

12 Ibid., hlm. 33.

13 H.M.N Purwosutjipto. 2003.Pengertian Pokok Hukum Dagang IndonesiaJilid 6. Jakarta: Djambatan, hlm. 10. 
bil) asuransi sebagai penikmatnya".

Dalam rumusan definisinya, Purwosutjipto menggunakan istilah "penutup" asuransi dan Penanggung. Definisi Purwosutjipto berbeda dengan definisi yang terdapat dalam Pasal 1 angka (1) Undang-Undang Perasuransian. Perbedaan tersebut adalah sebagai berikut: ${ }^{14}$

a. Dalam Undang-Undang Perasuransian dengan tegas dinyatakan bahwa pihakpihak yang mengikatkan diri secara timbal balik itu disebut Penanggung dan Tertanggung, sedangkan Purwosutjipto menyebutnya penutup (pengambil) asuransi dan Penanggung.

b. Dalam Undang-Undang Perasuransian dinyatakan bahwa "Penanggung dengan menerima premi memberikan pembayaran", tanpa menyebutkan kepada orang yang ditunjuk sebagai penikmatnya. Purwosutjipto menyebutkan membayar 1 (satu) orang yang ditunjuk oleh penutup (pengambil) asuransi sebagai penikmatnya.Kesannya hanya untuk asuransi jiwa selama hidup, tidak termasuk untuk yang berjangka waktu tertentu.

Kesepakatan untuk mengadakan perjanjian asuransi jiwa, berkaitan dengan dimulainya hak dan kewajiban dari penanggung dan tertanggung. Untuk menyatakan kapan dimulainya perjanjian asuransi yang dibuat oleh tertanggung dan penanggung, terdapat dua teori terjadinya perjanjian asuransi yakni: ${ }^{15}$

a. Teori tawar-menawar (bargaining theo$r y)$

Teori tawar-menawar dikenal juga dengan sebutan offer and acceptancethe-

14 Abdul Kadir Muhammad. 2005. Hukum Asuransi Di Indonesia. Bandung: Prenada Media, hlm. 197.

15 Ibid., hlm. 100. ory. Menurut teori ini, setiap perjanjian hanya akan terjadi antara keduapihak apabila penawaran dari pihak yang satu dihadapkan dengan penerimaan oleh pihak yang lainnya dan sebaliknya.

\section{b. Teori penerimaan (acceptance theory)}

Menurut teori penerimaan, saat terjadinya perjanjian bergantung pada kondisi konkret yang dibuktikan oleh perbuatan nyata (menerima) atau dokumen perbuatan hukum (bukti menerima).

Kedua teori tersebut, tertuang di dalam KUHD, yakni pada Pasal 257 ayat dan Pasal 255 KUHD.Dalam Pasal 257 ayat (1) KUHD ditegaskan bahwa perjanjian asuransi terjadi seketika setelah tercapainya kesepakatan antara para pihak, sehingga hak dan kewajiban timbal balik timbul sejak saat itu, walaupun sebelum polis ditandatangani. Hal ini mencerminkan bahwa perjanjian asuransi itu adalah perjanjian konsensual. ${ }^{16}$ Namun ketentuan tersebut, bertentangan dengan ketentuan Pasal 255 KUHD, yang juga menegaskan bahwa asuransi harus dibuat secara tertulis dalam bentuk akta yang disebut polis. Untuk mengatasi hal tersebut, Pasal 257 KUHD memberikan ketegasan, walaupun belum dibuatkan polis, asuransi sudah terjadi sejak tercapai kesepakatan antara tertanggung dan penanggung, yang disertai dengan adanya hak dan kewajiban dari penanggung dan tertanggung. Kesepakatan itu dibuktikan dengan nota persetujuan yang ditandatangani oleh tertanggung.

Selanjutnya, perjanjian asuransi jiwa juga dapat berakhir. Berakhirnya perjanjian asuransi jiwa, umumnya disebabkan oleh: ${ }^{17}$ 16 Yeni Salma Barlinti. 1998.Tentang Hukum
Asuransi,Jakarta: Binacipta, hlm. 35.

17 Abdul Kadir Muhammad. Op.Cit., hlm. 215. 
a. Terjadi evenemen

Dalam asuransi jiwa, satu-satunya evenemen yang menjadi beban penanggung adalah meninggalnya tertanggung. Terhadap evenemen inilah diadakan asuransi jiwa antara tertanggung dan penanggung.Apabila dalam jangka waktu yang diperjanjikan terjadi peristiwa meninggalnya tertanggung, maka penanggung berkewajiban membayar uang santunan kepada pihak ketiga yang ditunjuk oleh tertanggung sebagai ahli warisnya.

b. Jangka waktu berakhir

Apabila jangka waktu berlaku asuransi jiwa itu habis tanpa terjadi evenemen , maka beban risiko penanggung berakhir. Dengan demikian, asuransi jiwa berakhir sejak jangka waktu berlaku asuransi habis diikuti dengan pengembalian sejumlah uang kepada tertanggung.

c. Asuransi gugur

Menurut ketentuan Pasal 306 KUHD, pasal ini mengatur asuransi jiwa untuk kepentingan pihak ketiga. Kata-kata bagian akhir pasal tersebut, kecuali jika diperjanjikan lain memberi peluang kepada para pihak untuk memperjanjikan menyimpang dari ketentuan pasal ini, misalnya asuransi yang diadakan itu tetap dinyatakan sah asalkan tertanggung betul-betul tidak mengetahui telah meninggalnya pihak ketiga.

d. Asuransi dibatalkan

Asuransi jiwa dapat berakhir karena pembatalan sebelum jangka waktu berakhir.Pembatalan tersebut dapat terjadi karena tertanggung tidak melanjutkan pembayaran premi sesuai dengan perjanjian atau karena permohonan tertanggung sendiri.Pembatalan asuransi jiwa dapat terjadi sebelum premi mulai dibayar ataupun sesudah premi dibayar menurut jangka waktunya.

Asuransi adalah asas kerjasama dan gotong royong yang merupakan hal baru yang mana dalam Al-Quran pembahasan mengenai asuransi tidak kita temui dan juga belum pernah terjadi pada masa Rasul. Menurut Ibnu Qoyyim, tujuan hukum Islam adalah mewujudkan kemaslahatan masyarakat baik di dunia maupun di akhirat, menolak kemudaratan dan kemafsadatan serta mewujudkan keadilan yang mutlak. ${ }^{18}$ Setidaknya ada dua putusan waris yang berbeda berkenaan dengan dana asuransi tersebut.

Pertama, Putusan Mahkamah Agung RI Nomor 16 K/AG/2010 tanggal 30 April 2010. Putusan ini menetapkan setengah dari nilai asuransi Rp. 50.000.000,- (lima puluh juta rupiah) adalah harta waris yang harus dibagikan. Dalam putusan ini tidak ada pertimbangan yang spesifik berkenaan dengan dana asuransi, sehingga pertimbangan hukumnya dapat dilihat pada putusan tingkat pertama dan tingkat banding. Dalam putusan Pengadilan Tinggi Agama Makasar Nomor: 59/ Pdt.G/2009/PTA.Mks tanggal 15 Juli 2009 dan putusan Pengadilan Agama Makasar Nomor 732/ Pdt.G/2008/ PA.Mks tanggal 2 Maret 2009 menilai dana asuransi merupakan harta bersama antara pewaris dengan istrinya karena disamping asuransi tersebut atas nama pewaris juga premi yang telah dibayarkan kepada pihak Asuransi bersumber dari harta bersama. Majelis Hakim juga mempertimbangkan mengenai polis asuransi, bahwa penunjukan istri sebagai penerima uang asuransi sifatnya admistratif karena ahli waris sesungguhnya bukan hanya istri pewaris.

Kedua, Putusan Pengadilan Agama Bekasi Nomor: 1526/Pdt.G/2010/PA.Bks tanggal

18 Chairuman Pasaribu. 2004. Hukum Perjanjian Dalam Islam.Jakarta: Sinar Grafika,hlm.113. 
21 Desember 2011 yang telah dikoreksi oleh Pengadilan Tinggi Agama Bandung dengan putusan Nomor: 168/Pdt.G/2012/PTA.Bdg tanggal 19 Juli 2012, dan Putusan tersebut telah dikuatkan oleh putusan Mahkamah Agung RI Nomor: 197K/AG/2015 tanggal 11 Maret 2015. Putusan PTA Bandung tersebut menyertakan yurisprudensi Mahkamah Agung Nomor: 2831 K/Pdt/1996 tanggal 7 Juli 1999 dengan menegaskan bahwa dalam hukum asuransi jika terjadi evenemen (peristiwa yang tidak pasti/kematian) yang berhak menerima pembayaran uang pertanggungan adalah penikmat, biasanya berupa orang, badan, atau ahli waris yang ditunjuk dalam polis. Selain pertimbangan tersebut, asuransi tidak tunduk pada hukum perkawinan dan hukum kewarisan, oleh karenanya dana asuransi bukan harta bersama dan bukan harta warisan.

Dari dua Putusan diatas menunjukkan adanya perbedaan dalam menilai dana asuransi sebagai harta bersama atau sebagai hak kepemilikan tersendiri oleh penikmat/beneficiary yang tercantum dalam polis. Putusan pertama lebih melihat realitas pembayaran premi asuransi yang berasal dari harta bersama, sehingga dana asuransi tersebut harus dijadikan sebagai harta bersama. Sebaliknya putusan yang kedua menilai bahwa yang berhak atas dana asuransi adalah pihak yang dicantumkan dalam polis sesuai dengan yurisprudensi Mahkamah Agung Nomor: 2831 K/Pdt/1996 tanggal 7 Juli 1999 dengan menegaskan bahwa dalam hukum asuransi jika terjadi evenemen (peristiwa yang tidak pasti/kematian) yang berhak menerima pembayaran uang pertanggungan adalah penikmat, biasanya berupa orang, badan, atau ahli waris yang ditunjuk dalam polis.Dengan melihat pertentangan hukum tersebut, perlu dilakukan analisa ulang terhadap kedudukan dana asuransi dengan pendekatan hukum kewarisan Islam.

Perjanjian asuransi jiwa merupakan hasil persilangan antara hukum benda khususnya hukum waris testamentair dengan hukum perjanjian, dengan demikian perjanjianasuransi jiwa dapat disebut sebagai wasiat.Disebut sebagai wasiat oleh karena pewarisan adalah salah satu cara memperoleh hak milik atas suatu kebendaan dalam hal ini adalah uang pertanggungan, dan unsur-unsur mutlak suatu wasiat telah terpenuhi dalam perjanjian asuransi jiwa yaitu dibuat dalam bentuk formal (tertulis), berlakunya setelah terjadinya suatu peristiwa meninggal dunianya seseorang (dalam hal ini pemegang polis adalah tertanggung sendiri) dan dapat ditarik kembali dalam arti dapat dirubah-rubah penunjukan ahli waris atau penerima manfaat atas asuransi tersebut. Wasiat dalam berkenaan dengan asuransi jiwa ini bukanlah wasiat yang murni karena hal tersebut bukanlah konstruksi hukum suatu wasiat yang murni dan juga bukan merupakan konstruksi hukum perjanjian yang murni, oleh karena melibatkan pihak lain (dalam hal iniperusahaan asuransi) dan adanya pembatasan terhadap jenis harta (dalam hal ini hanya benda bergerak berupa uang) juga adanya pembatasan penerima manfaat atas uang pertanggungan (dalam hal ini hanya kepada orang yang mempunyai hubungan kepentingan asuransi atau insurable interest dengan Tertanggung).

Pada dasarnya memberikan wasiat merupakan tindakan ikhtiyariyah, yakni suatu tindakan yang dilakukan atas dorongan kemauan sendiri dalam keadaan bagaimanapun. Dengan demikian, pada dasarnya seseorang bebas apakah membuat atau tidak membuat wasiat. Akan tetapi, sebagian ulama berpendapat bahwa kebebasan untuk membuat wasiat atau tidak, itu hanya berlaku untuk orang-orang 
yangbukan kerabat dekat. ${ }^{19}$ Wasiat disini memiliki pengertian sebuah pernyataan kehendak oleh seseorang megenai apa yang akan dilakukan terhadap hartanya sesudah ia meninggal kelak.Demikianlah arti wasiat dalam hubungan dengan harta peninggalan dan hukum kewarisan.Dalam pelaksanaanya, terdapat beberapa syarat yang harus dipenuhi untuk terlaksananya wasiat itu dengan baik. ${ }^{20}$

Para ahli hukum Islam sepakat bahwa wasiat paling banyak adalah 1/3 (sepertiga) harta peninggalan pewaris. Dasar ketentuan dari pembagian besaran wasiat terdapat pada Kompilasi Hukum Islam (KHI) pasal 201 dan 209 ayat 2 dan juga berdasar dari pendapat hadis Sa'ad bin Abi Waqas seorang sahabat Nabi Muhammad SAW. Ahli sunnah berdasarkan hadis tersebut menetapkan bahwa wasiat boleh melampaui 1/3 (sepertiga) dari harta setelah dikurangi dengan semua utang. Walaupun demikian, apabila wasiat pewaris yang lebih dari 1/3 (sepertiga) harta peninggalan, maka diselesaikan dengan salah satu cara, yaitu ${ }^{21}$ :

a. Dikurangi sampai batas sepertiga harta peninggalan; atau

b. Diminta semua kesediaan ahli waris yang pada saat itu berhak menerima waris apakah mengikhlaskan kelebihan wasiat atas sepertiga harta peninggalan itu. Apabila mereka mengikhlaskan maka halal dan ibahah hukumnya pemberian wasiat yang lebih dari 1/3 (sepertiga) harta peninggalan itu.

Hukum kewarisan Islam mengandung berbagai asas yang memperlihatkan bentuk

19 Moh Muhibbin dan Abdul Wahid.2017.Hukum Kewarisan Islam. Jakarta: Sinar Grafika, hlm. 148.

20 Sayuti Thalib. 2016. Hukum Kewarisan Islam di Indonesia. Jakarta: Sinar Grafika. hlm.127.

21 Ibid., hlm.133-134. karakteristik dari hukum kewarisan Islam itu sendiri. Salah satunya adalah asas Keadilan berimbang 22 . Hukum Islam mengajarkan kewarisan secara adil dan berimbang Asas ini mengandung arti bahwa harus senantiasa terdapat keseimbangan antara hak dan kewajiban, antara yang diperoleh seseorang dengan kewajiban yang harus ditunaikannya. Laki-laki dan perempuan misalnya mendapatkan hak yang sebanding dengan kewajiban yang dipikulnya masing-masing (kelak) dalam kehidupan keluarga dan masyarakat. dalam sistem kewarisan Islam, harta peninggalan yang diterima oeh para ahli waris dari pewaris pada hakikatnya adalah pelanjutan tanggung jawab pewaris terhadap keluarganya.Oleh karena itu, perbedaan pembagian yang diterima oleh masing-masing ahli waris berimbang dengan perbedaan tanggung jawab masing-masing terhadap keluarga

Dalam Putusan Mahkamah Agung RI Nomor 16 K/AG/2010 tanggal 30 April 2010. Putusan ini menetapkan setengah dari nilai asuransi Rp. 50.000.000,- (lima puluh juta rupiah) adalah harta waris yang harus dibagikan. Dalam putusan ini tidak ada pertimbangan yang spesifk berkenaan dengan dana asuransi, sehingga pertimbangan hukumnya dapat dilihat pada putusan tingkat pertama dan tingkat banding. Dalam putusan Pengadilan Agama Makasar Nomor 732/Pdt.G/2008/ PA.Mks tanggal 2 Maret 2009 dan putusan Pengadilan Tinggi Agama Makasar Nomor: 59/Pdt.G/2009/PTA.Mks tanggal 15 Juli 2009menilai dana asuransi merupakan harta bersama antara pewaris dengan istrinya karena disamping asuransi tersebut atas nama pewaris juga premi yang telah dibayarkan kepada pihak Asuransi bersumber dari harta bersama. Majelis Hakim juga mempertim-

22 Faturrahman.Op.Cit.,hlm.135 
bangkan mengenai polis asuransi, bahwa penunjukan istri sebagai penerima uang asuransi sifatnya admistratif karena ahli waris sesungguhnya bukan hanya istri pewaris.

Telah diketahui bahwa asuransi termasuk bentuk mu'amalah antara sesama manusia, juga sangat penting bagi kepala keluarga yang mempunyai tanggung jawab atas kehidupan keluarganya apabila dia sudah tiada. Bagaimana dengan kelangsungan kehidupan keluarganya dikemudian hari bisa tercukupi. Islam sendiri mengajarkan bahwa meninggalkan ahli waris dalam keadaan kecukupan lebih utama daripada meninggalkannya dalam keadaan kekurangan (dalam QS. An Nisa (4): 9). Asuransi jiwa dapat memberikan kebutuhan ekonomi yang diperlukan karena perusahaan asuransi jiwa akan memberikan pembayaran bagi nasabah yang masih hidup setelah habis masa kontrak dan apabila nasabah meningal sebelum habis akhir pembayaran premi, maka ahli warisnya yang berhak menerima nilai asuransi (nilai sesuai yang dicantumkan dalam polis).

Harta warisan adalah semua harta benda yang ditinggalkan oleh seorang yang meninggal (pewaris). Jadi bentuk dari harta warisan tidak dibedakan apakah masih berupa tulisan (seperti polis) ataukah sudah berwujud harta benda. Islam sendiri memberikan batasan bahwa warisan adalah harta dari seseorang yang meninggal dunia berupa ${ }^{23}$

1. Harta kekayaan yang berwujud dan dapat di nilai dengan uang termasuk didalamnya piutang yang hendak ditagih. (aktiva)

2. Harta kekayaan yang merupakan utangutang yang harus dibayar pada saat meninggal dunia. (pasiva)

3. Harta kekayaan yang masih bercampur

23 Ibid., hlm.115. dengan harta bawaan masing-masing suami-isteri.

Jelas disini bahwa polis asuransi dapat dianggap sebagai harta warisan yang harus dibagi kepada para ahli warissah menurut Undang-Undang karena termasuk dalam piutang (aktiva) yang akan didapat dari perusahaan asuransi. Mengenai polis asuransi jiwa, bahwa penunjukan ahli waris sebagai penerima manfaat dari uang santunan asuransi jiwa sifatnya adalah admistratif karena ahli waris sesungguhnya bukan hanya ahli waris yang tercantum dalam polis asuransi jiwa saja. Hak dan kedudukan ahli waris dalam polis asuransi jiwa dibandingkan dengan ahli waris $a b$ instetato adalah khas dan unik, karena dari segi dasar keberadaannya ahli waris polis asuransi jiwa ditetapkan berdasarkan suatu perjanjian dengan pihak penanggung. Dari segi siapa yang berhak menjadi ahli waris, ahli waris dalam polis asuransi jiwa terbatas pada orang-orang yang mempunyai hubungan kepentingan (insurable interst) dengan pewaris. Dari segi harta warisan, ahli waris yang namanya tercantum sebagai penerima manfaat dalam polis asuransi jiwa hanya berhak atas harta warisan tertentu berupa sejumlah uang tertentu dalam hal ini ahli waris dalam polis asuransi jiwa hanya bisa menerima maksima 1/3 (sepertiga) dari boedel warisan.

Karena pada dasarnya Perjanjian asuransi jiwa merupakan hasil persilangan antara hukum benda khususnya hukum waris testamentair dengan hukum perjanjian, dengan demikian perjanjian asuransi jiwa dapat disebut sebagai wasiat.Disebut sebagai wasiat oleh karena pewarisan adalah salah satu cara memperoleh hak milik atas suatu kebendaan dalam hal ini adalah uang pertanggungan, dan unsur-unsur mutlak suatu wasiat telah terpenuhi dalam perjanjian asuransi jiwa yaitu 
dibuat dalam bentuk formal (tertulis), berlakunya setelah terjadinya suatu peristiwa meninggal dunianya seseorang (dalam hal ini pemegang polis adalah tertanggung sendiri) dan dapat ditarik kembali dalam arti dapat dirubah-rubahpenunjukkan ahli waris/ penerima manfaat atas asuransi tersebut. Dari segi kedudukannya, ahli waris dalam polis asuransi jiwa hanya sebagai kreditur (tidak menggantikan hak dan kewajiban pewaris) dan hanya mempunyai hak tuntut kepada penanggung.Ahli waris legitimaris berhak menuntut hak bagian mutlak yang dilindungi oleh undang-undang (legitime portie) atas uang pertanggungan yang melanggar hak bagian mutlaknya karena pada saat meninggalnya pewaris, hak atas polis berubah menjadi hak dari polis, dan pada saat itu pula kedudukan uang pertanggungan masuk kedalam budel harta warisan, bukan semata-mata sebagai piutang yang dapat ditagih dari penanggung.

\section{PENUTUP}

\section{Kesimpulan}

1. Dalam Putusan Mahkamah Agung RI Nomor $16 \mathrm{~K} / \mathrm{AG} / 2010$ tanggal 30 April 2010 lebih melihat realitas pembayaran premi asuransi yang bersumber dari harta bersama, sehingga dana asuransi tersebut harus dijadikan sebagai harta bersama. Majelis Hakim juga mempertimbangkan mengenai polis asuransi, bahwa penunjukan istri sebagai penerima uang asuransi sifatnya administratif saja karena ahli waris sesungguhnya bukan hanya istri pewaris.

Sebaliknya dalam putusan Mahkamah Agung RI Nomor: 197K/AG/2015 tanggal 11 Maret 2015bahwa yang berhak atas dana asuransi adalah pihak yang dicantumkan dalam polis. Dalam Putusan yang kedua, Kedudukan dana asuransi tersebut telah ditegaskan dalam putusan Mahkamah Agung Nomor: 2831 K/ Pdt/1996 tanggal 7 Juli 1999. Yurisprudensi tersebut mengandung dua kaidah hukum.Pertama, pembayaran uang asuransi harus diberikan kepada tertanggung yang namanya tercantum dalam polis, Kedua, pembayaran uang asuransi yang menyimpang dari ketentuan Polis merupakan perbuatan melawan hukum.

2. Mengenai polis asuransi jiwa, bahwa penunjukan ahli waris sebagai penerima manfaat dari uang santunan asuransi jiwa sifatnya adalah admistratif karena ahli waris sesungguhnya bukan hanya ahli waris yang tercantum dalam polis asuransi jiwa saja. Hak dan kedudukan ahli waris dalam polis asuransi jiwa dibandingkan dengan ahli waris $a b$ instetato adalah khas dan unik, karena dari segi dasar keberadaannya ahli waris polis asuransi jiwa ditetapkan berdasarkan suatu perjanjian dengan pihak penanggung. Dari segi siapa yang berhak menjadi ahli waris, ahli waris dalam polis asuransi jiwa terbatas pada orang-orang yang mempunyai hubungan kepentingan (insurable interst) dengan pewaris.Dari segi harta warisan, ahli waris dalam polis asuransi jiwa hanya berhak atas harta warisan tertentu berupa sejumlah uang tertentu dalam hal ini ahli waris dalam polis asuransi jiwa hanya bisa menerima maksimal 1/3 (sepertiga) dari boedel warisan. Karena pada dasarnya Perjanjian asuransi jiwa merupakan hasil persilangan antara hukum benda khususnya hukum waris testamentair dengan hukum perjanjian, dengan demikian perjanjianasuransi jiwa dapat disebut sebagai wasiat. 


\section{Saran}

1. Sebagai bentuk pengaman menghindari resiko sengketa di kemudian hari, maka dalam setiap perjanjian pertanggungan pada kolom dalam form pengajuan asuransi jiwa yang berisikan penerima manfaat/beneficiary/ahli waris yang ditunjuk dilampirkan pula dokumen-dokumen identitas dari penerima manfaat yang menyatakan/membuktikan adanya hubungan kepentingan (insurableinterest) dengan pihak Tertanggung.

2. Ahli waris harus diberi penjelasan siapa yang akan menjadi penerima manfaat dari asuransi jiwa yang dibeli oleh tertanggung apabila si tertanggung meninggal dunia dalam masa pertanggungan. Agar terdapat suatu kepastian hukum bagi Ahli waris dalam hal Pewarisan Santunan asuransi jiwa. Maka, hendaknya Pemegang Polis (Pewaris) setelah membeli polis asuransi jiwa alangkah baiknya membuat surat wasiat yang isinya apabila si pewaris meninggal dunia maka Uang Pertanggungan yang muncul ketika pewaris meninggal dunia akan diberikan kepada ahli waris yang nama tercantum dalam polis asuransi jiwa yang ditinggalkan pewaris. Hal ini diperlukan agar tidak terjadi sengketa dikalangan para ahli waris nantinya. Sehingga dengan adanya wasiat tersebut maka, ahli waris yang namanya tercantum dalam polis asuransi jiwaberhak menerima maksimal 1/3 (sepertiga) dari boedel warisan dan sisanya bisa dibagikan kepada para ahli waris lain yang namanya tidak tercantum sebagai penerima manfaat dalam polis asuransi jiwa.

\section{BIBLIOGRAFI}

Abdurracham, A. 1991. Ensiklopedia Ekonomi Keuangan dan Perdagangan.Jakarta: PT. Pradnya Paramita

Barlinti, Yeni Salma. 1998.Tentang Hukum Asuransi, Jakarta: Binacipta

Faturrahman. 2000. Ilmu Waris. Bandung: PT.Al Ma'arif

Mahkamah Agung RI. 2000. Yurisprudensi Mahkamah Agung RI. Jakarta: MARI

Muhammad, Abdul Kadir. 2005. Hukum Asuransi Di Indonesia. Bandung: Prenada Media

Muhibbin, Moh dan Abdul Wahid.2017.Hukum Kewarisan Islam. Jakarta: Sinar Grafika

Muhjad, M. Hadin dan Nunuk Nuswardani. 2012. Penelitian Hukum Indonesia Kontemporer. Yogyakarta: Genta Publishing.

Mulhadi. 2016. Dasar-dasar Hukum Asuransi. Medan: PT RajaGrafindo Persada.

Pasaribu, Chairuman. 2004. Hukum Perjanjian Dalam Islam. Jakarta: Sinar Grafika

Permana, Sugiri Permana. 2016. Kajian yuridis terhadap kedudukan dana asuransi. artikel internet. http://www.google.co.id/ url? $\mathrm{sa}=\mathrm{t} \&$ souce $=$ web $\& \mathrm{RCT}=\mathrm{j} \&$ url $=\mathrm{ht}$ tp//journal.uinjkt.ac.id. Diakses Tanggal 15 Maret 2018.

Purwosutjipto, H.M.N. 2003.Pengertian Pokok Hukum Dagang IndonesiaJilid 6. Jakarta: Djambatan

Satrio, J. 2002. HukumWaris di Indonesia. Bandung: Alumni.

Sula, Muhammad Syakir. 2004. Asuransi Syariah Konsep dan Sistem Operasional. Jakarta: Gema Insani Press

Thalib, Sayuti. 2016. Hukum Kewarisan Islam di Indonesia. Jakarta: Sinar Grafika.

Usman, Suparman. 2002. Fiqih Mawaris. Jakarta: Gaya Media Pratama. 
PeraturanPerundang-Undangan

Kitab Undang-UndangHukumPerdata.

Kitab Undang-Undang Hukum Dagang.

Undang-undangNomor 1 Tahun 1974 Tentang

Perkawinan (Lembaran Negara Republik Indonesia tahun 1974 Nomor 1)

Undang-undangNomor 40 Tahun 2004 Tentang Sistem Jaminan Nasional (Lembaran Negara Republik Indonesia Nomor 5256)

Undang-undangNomor 40 Tahun 2014 Tentang Perasuransian (Lembaran Negara Republik Indonesia Nomor 5618)
Instruksi Presiden RI Nomor 1 Tahun 1991 Tentang Kompilasi Hukum Islam

Putusan Mahkamah Agung Republik Indonesia Nomor $16 \mathrm{~K} / \mathrm{AG} / 2010$.

Putusan Mahkamah Agung Republik Indonesia Nomor 197 K/AG/2015. 